\title{
Application of Minerals in Low Saline Water Culture Systems of L. vannamei
}

\author{
T. Suguna* \\ Fisheries Research Station, S.V. Veterinary University, West Godavari, \\ Andhra Pradesh - 534 199, India \\ *Corresponding author
}

\section{A B S T R A C T}

\begin{tabular}{l} 
Ke y w o r d s \\
$\begin{array}{l}\text { L. Vannamei, } \\
\text { Low saline waters, } \\
\text { Minerals usage }\end{array}$ \\
\hline Article Info \\
$\begin{array}{l}\text { Accepted: } \\
\text { 07 August } 2020 \\
\text { Available Online: } \\
\text { 10 September } 2020\end{array}$ \\
\hline
\end{tabular}

\section{Introduction}

Aquaculture is one of the fast growing sector in state and producing major share of shrimp and fish in the country thereby standing as "Aqua Hub of India". Andhra Pradesh state is producing more than $65 \%$ of culture shrimp in the country. The government of Andhra Pradesh has taken up a proactive role to promote sustainable and eco-friendly shrimp aquaculture and for further expansion as a means to increase production, an important tool for development and income generation in rural areas and as a source of foreign exchange earnings through trade. Out of the 1.96 lakhs ha of aquaculture area, an extent of
0.80 lakh ha is under L. vannamei culture (both brackish water and freshwater). Since $L$. vannamei is giving very profitable results, many aqua farmers are shifting to this species. Low culture period associated with greater demand and price for export, offering enhanced scope for area expansion in the state.

The shrimp L. vannamei are traditionally cultured in coastal or estuarine waters with salinities ranging from 15 to 40 ppt. However, due to various social and economical reasons shrimp farming of Pacific White leg shrimp is now being done successfully in many parts of the country using low to medium saline 
waters ( 0 to $10 \mathrm{ppt}$ ) from the irrigation drains, rivers etc. Depending on their source, waters available for shrimp culture are of different salinities, and therefore possess different ionic composition. Such low saline waters may require supplementation of minerals to achieve desired productivity. The post larvae (PL) of vannamei are able to tolerate wide range of salinity from 0.5 to 40 ppt. Further it is proved that L. vannamei can be cultured successfully in low saline water or even freshwater.

On account of culturing the shrimp in low saline waters, various problems are perceived in the culture systems. The culture practices adopted in coastal or estuarine bodies cannot be applicable to low saline water bodies. In general, the shrimp requires the water with ionic profile of its native coastal water bodies. As the culture is carried out in various chloride level of water, the general physiology of the shrimp is altered widely which affects its survival, growth and osmoregulatory function.

\section{Importance of minerals}

Minerals have many physiological functions to maintain acid-base balance. The Calcium (Ca) and Magnesium ( $\mathrm{Mg}$ ) are considered to be very important for moulting and new shell formation. The ratios of $\mathrm{Na}: \mathrm{K}$ and $\mathrm{Mg}$ : $\mathrm{Ca}$ play in important role in physiological functions.

\section{Mineral requirements for shrimp farming}

In addition to basic water quality parameters, the mineral profile of water is important in $L$. vannamei culture. Actual mineral requirement is difficult to quantify due to the variability in the ionic profiles of pond waters. The bio availability of minerals will be a function of their concentration in water. In general, levels of minerals in pond water have to be more or less similar to the levels in seawater diluted to the same salinity. However, pond water characteristics of even the very closely located ponds will not be exactly the same. It is reported that the survival of post larvae (PL) was good in water having salinity of above 4 ppt than 2 ppt (Devis et al., 2004). However the survival varies with various minerals such as Sodium $(\mathrm{Na}+)$, Potasium $(\mathrm{K}+)$, Magnesium (Mg 2+), Calcium $(\mathrm{Ca} 2+)$, Chloride (Cl-) and Sulphate (So4 2-) subsist in the culture system. Limiting of any one of the above minerals will lead to poor survival and growth. Though all these minerals are important, $\mathrm{K}$ and $\mathrm{Ca}$ are always considered most important and equal ratio is preferred. It can be corrected through either modification of ionic level either in nutrition or water.

\section{Ionic Ratios}

Ionic ratios are quite different between seawater and different source waters. The ratio of $\mathrm{Na}$ (Sodium) to $\mathrm{K}$ (Potassium) and $\mathrm{Mg}$ (Magnesium) to $\mathrm{Ca}$ (Calcium) in water appears to be more important than pond water salinity. Improper ratios of these minerals in water lead to osmotic stress which has cascading effect on growth and survival of the shrimp. The $\mathrm{Na}$ : $\mathrm{K}$ and $\mathrm{Mg}$ : $\mathrm{Ca}$ ratios should be preferably $28: 1$ and 3.4:1 respectively. It should be noted that although high levels of $\mathrm{Ca}$ also seem to be necessary, the ratio of $\mathrm{Ca}$ : $\mathrm{K}$, which is about 1:1 in seawater, may also be important. In waters where the $\mathrm{Ca}$ : $\mathrm{K}$ and $\mathrm{Na}$ : $\mathrm{K}$ ratios are high, the addition of $\mathrm{K}$ to reduce these ratios in low saline waters increases the shrimp growth.

In general it is opened that $\mathrm{K}, \mathrm{Mg}$ are common deficient mineral in low saline water, despite it may vary with source of water used and location, it divulges the fact that simple blind addition of either $\mathrm{K}$ or $\mathrm{Mg}$ source may not solve the problems. The level of minerals requirement is to be studied time 
to time and accordingly dose of minerals required is to be decided. Excess addition of minerals will alter the other mineral ratio which in turn harms the environment and growth of the shrimp being reared. There is no standard chart for addition of required minerals in culture water for all the regions and seasons. Nevertheless, every farmers should have fundamental knowledge on minerals requirement for this culture.

The interaction of salinity and addition of essential minerals like $\mathrm{K}, \mathrm{Mg}, \mathrm{NaCl}$, $\mathrm{Ca}$ etc. are generally regulating the problems in shrimp culture in low saline waters. Further, it is noticed that ionic profile of the water of all the ponds which obtained from the same bore, of the same farm may not be similar. Hence frequent ionic profile analysis is to be conducted before stocking the ponds every time, during culture and every year since the addition of the above mineral fertilizers may be fatigued by adsorption by the pond bottom or leaching or draining of pond water during harvesting.

The farmers, farming the shrimp Vannamei in low saline waters should get their bore well water tested to know the profile of the minerals in the bore water. The deficiency of any mineral can be corrected by altering the ionic profile ratio, since it is very difficult to maintain the correct minerals or ions in low saline waters similar to coastal waters. More over the ionic composition of water used for culture should be similar to sea water. The Vannamei being reared in such waters will only yield good survival and growth. Similarly single salt solution is also not suitable for vannamei culture, since different ionic compositions are required for maintaining the physiological regulation in shrimps, despite sodium and chloride are major salts for its osmoregulation (Cawthrone et al 1983).

\section{Effect of mineral deficiencies}

Vannamei cultured in coastal waters do not pose problems of mineral deficiency since they get adequate minerals for their physiological requirement both from medium and feed. It is reported that shrimps being grown in low saline waters are often in stress or lethargic even if it is handled gently, or slowly die off. The post larvae stage is considered as important one in tolerating the salinity, since it has good osmoregulatory capacity. PL 15-20 can tolerate the salinity variation rather than PL 10-12. Through proper acclimatization the tolerance can be achieved. Mineral deficiency can be identified through paling of tail, cramping and death which is mainly due to ionic imbalances in the culture water. The vannamei cultured in low saline waters usually will not get such minerals either from water or feed, since there is no specific feed for the shrimps cultured in low saline waters. Farmers are using the same feed which is developed for brackish water or sea water culture, for their shrimps being grown in low saline waters. Potasium is most important ion for the survival and growth of shrimps especially for post larvae (Shiau and Hsieh, 2001) and its minimum requirement level is 1 ppm (Mcraw and Scarpa, 2003) and it is known that use of mixed salt containing chlorides of $\mathrm{Na}+, \mathrm{K}+\mathrm{Ca} 2+$, and $\mathrm{Mg} 2+$ yielded promising results in low saline waters. The growth and survival are increased while supplementing the $\mathrm{K}+$ ions equal to its concentration in equivalent salinity. It is reported that osmotic regulation in the shrimp is not affected in mixed salt and sea salt environments even if it is below $2 \mathrm{ppt}$ (Sowers et al., 2005). Another opinion of researcher is that low salinity does not affect osmotic regulation in vannamei. Generally the survival of shrimp is positively correlated with ions like $\mathrm{K}, \mathrm{Mg}$ and $\mathrm{SO}_{4}$ and negatively correlated with ion concentration. It is also reported that shrimp which are exposed to 
water containing higher level of monovalent ions succumb good survivals. The addition of rock salts in the culturing water for stocking of seeds will increase the conductivity for few weeks. i.e. change of monovalent into divalent cations. Frequent addition of little salt with other minerals is required for maintaing the monovalent cations to ensure good survival and growth over the course of the culture.

\section{Mineral supplementation through feed}

The shrimp Vannamei is a euryhaline species and tolerate wide range of salinities. The shrimp which is cultured in low saline water faces osmotic regulation between the media and its body. To balance the osmotic pressure, the shrimp intakes more water through gills and intestine. Minerals like $\mathrm{Na}, \mathrm{K}, \mathrm{Mg}$ and Chloride play major role in maintaing the osmoregulatory function in the shrimps being cultured in low saline waters. It is reported that in low saline waters, shrimp is unable to take macro minerals like $\mathrm{Na}, \mathrm{Mg}, \mathrm{K}$ etc from the medium. Addition of such minerals through fertilizers may be costly. Considering this, the problem of mineral deficiencies is encountered through addition of these minerals along with feed. It is reported that inclusion of such macro minerals through feed enhances the growth of shrimp. Mainly the major minerals like $\mathrm{K}$ and $\mathrm{Mg}$ are supplemented with diet of the shrimps and the same is proved successfully in yielding good survival and good growth in shrimps (Roy and Davis, 2010). Other than minerals, components like, highly unsaturated fatty acids (HUFA), Carbohydrates, Stress releasers like astaxanthiun, immunity booster like betaine, amino acids are also incorporated through feed to tolerate the salinity variation. It should be understood that excessive inclusion of either of minerals will not yield good result.

\section{Mineral supplementation through water}

Water modification approaches are more effective compared to the dietary modification strategies, though the cost of ionic fortification is comparatively high when the culture area is large. The ionic composition of water is more important than salinity since it determines the physiology and growth of the shrimps. It is reported that Vannamei can grow in the water containing less than 140 ppm of cations. In low saline waters, $\mathrm{K}$ and $\mathrm{Mg}$ are highly deficient and it may vary area to area especially while taking ground water. It has been observed that survival and growth of shrimp inversely proportional to $\mathrm{Na}: \mathrm{K}$ ratio (Roy et al, 2007). Calcium is frequently absorbed by the animal especially after molting since it does not have internal calcium reserves as freshwater crustaceans (McWhinnie 1962). Magnesium is also another important mineral which plays a major role in shrimps metabolism. The concentrations of these minerals or ions vary from water to water and they cannot be maintained as required. Hence, ratio of these minerals is considered to be significant one. The ratio of these ions present in coastal water should be maintained in low saline waters also irrespective of salinity. The ratio of $\mathrm{Ca}: \mathrm{K}$ is $1: 1$ in coastal water, if any changes in the low saline water, it can be brought back by addition of ' $\mathrm{K}$ ' instead of ' $\mathrm{Ca}$ '. Similarly other ionic ratios being maintained in low saline waters are $\mathrm{Na}: \mathrm{K}$ and $\mathrm{Mg}: \mathrm{Ca}$ are 28:1, it may be upto 40:1 and 3.4:1 respectively. Otherwise it can be stated that required minimum ionic compositions are $\mathrm{Na}: 4000$ ppm, Ca: 160 ppm, K: 150 ppm, Mg: 525 ppm, Cl: $7500 \mathrm{ppm}$ and Nitrate: 0.03 ppm. Ionic composition of pond water will vary time to time and crop to crop. Hence, frequent analysis of ionic composition in low saline waters will give an idea of about amount of minerals to be added to maintain the required ionic ratios. Further $\mathrm{K}$ and $\mathrm{Mg}$ will be 
adsorbed largely in the pond soil. Survival of vannamei is more in the water containing high concentration of ions $\mathrm{Na}+$ and $\mathrm{K}+$ than $\mathrm{Ca} 2+$ and $\mathrm{Mg} 2+$. The requirement of ionic compositions or minerals can be calculated in simple way by multiplying the existing salinity with multiplication factor of every ion. The multiplication factor for $\mathrm{Na}, \mathrm{K}, \mathrm{Mg}$, $\mathrm{Ca}, \mathrm{Cl}$ and Sulphate is 304.5, 10.7, 39.1, 11.6, 551 and 78.3 respectively. For example $7 \mathrm{ppt}$ salinity water required potassium is $7 \times 10.7=$ $74.9(75 \mathrm{ppm})$. It means $300 \mathrm{~kg}$ potassium is required for one acre in one meter depth without considering the existing potassium level in the pond water. Another method of calculating the potassium for the above salinity is $(0.38 / 35) \times 7 \times 1000=76 \mathrm{ppm}$. Both ways are also almost similar. However there is no standard rule for deterring the level of mineral requirement since there are many interactions between minerals in low saline waters (Davis et al., 2004). The alkalinity of pond water also determines the kind of minerals to be added. If it is less, agricultural lime, calcium carbonate is to be added whereas in the case of high Calcium sulphate (Gypsum) may be preferred if the pond water hardness is not alarming. Similarly, if $\mathrm{Na}, \mathrm{K}$, or $\mathrm{Mg}$ deficiency is found, many agricultural products like Murate of Potash, Potassium sulphate, Potassium chloride, Magnesium sulphate (Epsom), Magnesium chloride, Potassium Magnesium sulphate (K-Mag), Sodium chloride (Rock salt).

In conclusion it has been proved in many areas that the culture of $L$. vannamei is remarkably successful in freshwater also. With quality seed and pollution free environment, the culture of vannamei will be promising. Survivality of seed depends on the selection of PL stage and proper acclimatization.

Modification of nutritional / dietary and environmental is feasible and economically viable by reducing the water exchange and supplementary addition of minerals through feed. Water modification and directly modification approaches have been explored by researchers and farmers to improve the growth and survival of marine shrimp in low saline waters. Modification of rearing medium with fertilizers is more effective than directly modification techniques at improving the growth, survival and osmoregulatory capacity of marine shrimp reared in low saline waters. Zero water exchange or minimal water exchange and frequent removal of sludge from the pond bottom keep the culture environment free from diseases. Further, it reduces operational costs and loss of nutrients from the culture ponds. It is proved that no growth and survival difference is observed between water exchanged and zero water exchanged ponds (Hopknis et al, 1996). Culture of shrimp in inland waters using ground water is alternative to the coastal aquaculture which enhances the shrimp production in the country. However, digging of deep bore, taping high salinity may salinize the nearby productive soil. Environmental degradation may be avoided in culture of Vannamei, in low saline water also, when there is proper maintenance of ionic ratios.

\section{References}

Cawthorne, D.F., Beard, T., Davenport J. and Wickins J.F., 1983. Responses of juvenile Penaeus monodon (Fabricius) to natural and artificial sea waters of low salinity. Aquaculture 32, 165-174 pp.

Davis, D.A., Saoud, I.P., Boyd, C.E., and Rouse, D.B., 2005. Effects of potassium, Magnesium, and age on growth and survival of Litopenaeus vannamei post-larvae reared in inland low salinity well waters in West Alabama. J. World Aqua. Society, 36, 403-406. 
Davis, D.A., T.M. and Boyd, C.E., 2004. Acclimating Pacific White Shrim, Litopenaeus vannamei, to Inland, Low-Salinity Wates, SRAC Publication No. 2601, 1-8 pp.

Hopkins, J.S., Paul, A. Sandifer, Browdy, C.L. and Holloway, J.D., 1996. Comparison of exchange and noexchange water management strategies for the intensive pond culture of marine shrimp. J. ShellfishRes., 15:441-445.

Mc Graw, W.J. and Scarpa, J., 2003. Minimum environmental potassium for survival of pacific white shrimp Litopenaeus vannamei (Boone) in freshwater. J. Shellfish Res 22:263267.

Mcwhinnie, M.A., 1962. Gastrolit growth and calcium shifts in the fresh water crayfish Orconectes virilis. Comp. Biochem. and Phy., 7:1-14.

Roy, L.A. and Davis, D.A., 2010. Requirements for the culture of the Pacific white shrimp Litopenaeus vannamei reared in low saline waters: Water modifications and nutritional strategy for improving production En: Cruz-Suarez, L.E., Ricque_marie, D.,
Tapia-Salazar, M., Nieto-Lopez, M..G., Villarreal-Cavazos, D.A., Gamboa Delgado, J. (Eds), Advances en Nutricion Acuicola X-Memorias del X Simposio International de Nutricion Acuicola, 8-10 de Noviembre, San Nicolas de los Garza, N.L., Mexic. ISBN en tramite. Universidad Autonoma de Nuevo Leon, Monterrey, Mexico, pp. 61-78.

Roy, L.A., Davis, D.A., Saoud, I.P., and Henry, R.P., 2007. Effects of varying levels aqueous potassium and magnesium on survival, growth and respiration of the Pacific white shrimp, Litopenaeus vannamei, reared in low salinity waters. Aquaculture 262" 461-469.

Shiau, S.Y. and Hsieh, J.F., 2001. Dietary potassium requirement of juvenile grass shrimp. Penaeus monodon. Fish, Sci. 67, 592-595.

Sowers, A.D., Gatlin, D.M., Young, S.P., Isely, J.J., Browdy, C.L. and Tomasso, J.R., 2005. Responses of Litopenaeus vananmei (Boone) in water containing low concentrations of total dissolved solids. Aqua. Res., 36: 819-823.

\section{How to cite this article:}

Suguna, T. 2020. Application of Minerals in Low Saline Water Culture Systems of $L$. vannamei. Int.J.Curr.Microbiol.App.Sci. 9(09): 516-521. doi: https://doi.org/10.20546/ijcmas.2020.909.065 